\title{
Evaluation of the chloride penetration and service life of self-healing concretes activated by crystalline catalyst
}

\section{Avaliação da penetração de cloretos e da vida útil de concretos autocicatrizantes ativados por aditivo cristalino}
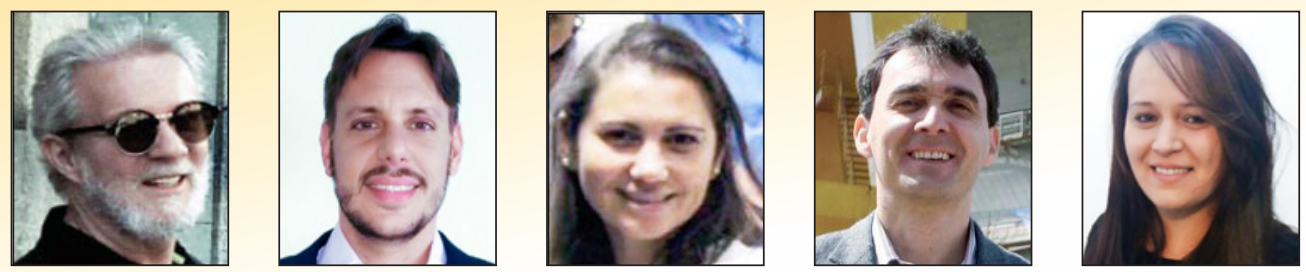

P. HELENE a paulo.helene@concretophd.com.br

G. GUIGNONE gcgarquiteto@gmail.com

G. VIEIRA ${ }^{b}$ geilma.vieira@gmail.com

L. RONCETTI ${ }^{\circ}$ leonardo@techcon.eng.br

F. MORONIC

nanda.moroni.fm@gmail.com

\begin{abstract}
The main cause of concrete structures deterioration is related to the resistance against the penetration of aggressive agents. Aiming at increase the impermeability and reduce the diffusivity of concrete elements, making it less susceptible to the ingress of chloride ions, the use of crystalline catalyst emerges as a good alternative. Its mechanism of autogenous healing enhances the natural pore-filling process of concrete. The aim of this study is to investigate the influence of the use of crystalline catalyst on the chloride ions penetration and service life prediction of concrete. For the concrete mixtures production, it was used blast-furnace slag blended cement, three different water/cement $(\mathrm{w} / \mathrm{c})$ ratios $(0.45 ; 0.55 ; 0.65)$, with and without crystalline catalyst, totaling six different mixtures. The concrete specimens were cured in a moist chamber and tested at 28 and 91 days. It was performed tests of compressive strength, rapid chloride permeability (ASTM C1202:12), and silver nitrate colorimetric indicator. The results show that, compared to the reference mixture, the use of crystalline catalyst conserved the compressive strength and reduced the chloride ions penetration up to $30 \%$, increasing service life up to $34 \%$.
\end{abstract}

Keywords: durability, reinforced concrete, chloride ions, crystalline admixture.

\section{Resumo}

A razão predominante da deterioração das estruturas de concreto armado está relacionada com a capacidade de resistência contra a penetração de agentes agressivos. A fim de favorecer a elevação da estanqueidade de elementos de concreto e a redução da difusividade dos concretos, tornando-os menos suscetíveis ao ingresso de íons cloreto, a utilização de aditivo cristalino desponta como opção muito interessante. Seu mecanismo de autocicatrização autógena potencializa o processo de colmatação natural do concreto. Este trabalho objetivou investigar a influência da utilização desses aditivos autocicatrizantes cristalinos no que tange ao avanço de íons cloreto e à estimativa de vida útil em concretos. Para a produção dos concretos foi utilizado cimento Portland com escória de alto forno, considerando três relações água/cimento $(0,45 ; 0,55 ; 0,65)$, sem e com o aditivo cristalino, totalizando seis proporções de materiais. Os corpos de prova foram curados em câmara úmida e ensaiados nas idades de 28 e 91 dias. Foram realizados ensaios de compressão axial, penetração acelerada de íons cloreto, ASTM C1202:12, e ensaios de indicadores colorimétricos com aspersão de nitrato de prata. Após análise efetuada, os resultados demonstraram que, comparativamente ao concreto de referência, o uso do aditivo cristalino resultou na conservação da resistência à compressão em concretos, na redução da penetração de cloretos em até $30 \%$, e, na elevação da vida útil de projeto, VUP, em até $34 \%$.

Palavras-chave: durabilidade, concreto armado, íons cloreto, aditivo cristalino.

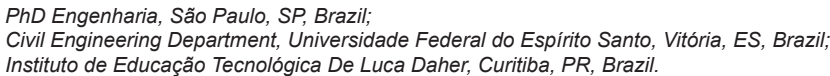




\section{Introduction}

The chloride ions penetration is one of the main mechanisms of deterioration of reinforced concrete structures. This is due, partly, to the possibility of these ions being transported to the interior of the concrete, reaching the steel reinforcement and causing corrosion [1-3]. A preventive measure that can be applied to reduce the entrance of this aggressive agent in the concrete is the use of crystalline catalysts, which induce the pore-filling effect, thus, minimizing the chloride ion penetration.

It is known that in similar conditions of consumption and properties of aggregates, the more porous the concrete and the interconnection between the pores, higher is the penetration of aggressive agents [4]. Additionally, according to Sousa [5], the higher the w/c ratio, higher is the concrete porosity. According to Neville [6], what determines the penetration and movement of the aggressive agents through the concrete is the hydrated paste structure and its chemical and physical characteristics, the superficial concentration of aggressive agents and the environmental conditions.

Due to the need of concretes which are more resistant to the penetration of aggressive agents, especially the chloride ions, it is important to highlight the use of crystalline catalysts. The study of its application in elements of concrete structures exposed to marine environments is relevant for the prevention of pathological manifestations. Thus, becomes crucial the study of these crystalline catalysts in concretes exposed to chloride ions contamination.

The autogenous healing is defined as a self-healing property, where the healing is caused by the concrete hydrated compounds, which can be or not activated. From the microstructure aspect, the autogenous healing is characterized by the use of microcapsules filled with healing agents or by the vascularization of hollow tubes which pump the healing agents [7].

It is worth noting that the autogenous healing mechanism tends to occur by the concrete natural pore-filling due to the chemical reactions (continuous hydration, $\mathrm{CaCO}_{3}$ formation) and mechanical actions (loose particles in the cracks or suspended in water), or even due to the self-healing phenomenon caused by active catalysts. The production of self-healing concretes by the autogenous approach id favored by the use of special component, such as the crystalline catalyst [8].

In this context, the crystalline catalyst with self-healing agent, subject of analysis in this study, is defined as a synthetic cementitious material classified as a hydrophilic waterproofing material or also as a hydrostatic permeability reducing admixture. Its reactive compounds combine with the concrete $\mathrm{Ca}(\mathrm{OH})_{2}$ forming crystalline products which disconnect the pores and fill the cracks. It is important to note that the crystalline products can only have a positive effect when there is enough humidity, since water availability is crucial for the autogenous healing reactions [9].

The admixture active chemical substances use water as a medium of diffusion to migrate and ingress in the concrete capillaries and cracks. The process is based in the precipitation of a chemical reaction, promoted by the catalyst, between the water and the cement hydration byproducts, forming a new insoluble crystalline structure of calcium silicate hydrate (C-S-H), calcium carbonate $\left(\mathrm{CaCO}_{3}\right)$, apatite crystals $\left(\mathrm{CaF}_{2}\right)$ and enstatite crystals $\left(\mathrm{MgSiO}_{3}\right)$. This crystalline structure fills the pores making the concrete less permeable due to the cracks pore-filling [10].

Researches have evaluated the effect of crystalline catalyst in concretes [11-18]. However, it is relevant to know its potential regarding the mitigation of chloride ions penetration and the increase of service life of concrete structures, characterized, according to Helene [1], by the initiation of corrosion or even by the period in which the chloride ions reach the steel reinforcement in sufficient concentrations to dissolve the steel passivation film. In this study, it will be analyzed the influence of the use of self-healing crystalline catalyst in concretes focusing on chloride ions penetration and service life prediction.

\section{Materials and methods}

\subsection{Materials}

The cement used for the specimens' preparation was blast-furnace slag blended cement, sulfate resistant, CP III 40 RS. Due to its characteristics, this cement has been the most used in the district of Espírito Santo - place where the study was performed. The main reason for its use is the increased resistance against chemical attack, since there are many construction projects close to the sea in the district. The proximity with the sea means salt spray exposure, the main responsible for the chloride ions penetration in concrete structures. It is also worth noting the autogenous healing mechanism promoted by the use of blast-furnace slag cement. Thus, in this context, it is also intended to assess the catalyst efficiency in concretes with high slag content.

The fine aggregate used was quartz sand, previously washed and kiln dried between $105^{\circ} \mathrm{C}$ and $110^{\circ} \mathrm{C}$. As coarse aggregate, crushed rock originated from diabase from the city of Serra-ES was used. Aiming at provide an adequate workability between the different mixtures investigated, it was used a plasticizer chemical admixture of normal setting, which proportion recommended by the manufactures is 0.2 to $2 \%$ of the cement weight.

Table 1 presents the chemical composition of the crystalline catalyst and the cement used.

\section{Table 1}

Typical chemical composition of the components, in percentage

\begin{tabular}{|c|c|c|c|c|c|c|c|c|c|}
\hline Components & $\mathrm{SiO}_{2}$ & $\mathrm{Al}_{2} \mathrm{O}_{3}$ & $\mathrm{Fe}_{2} \mathrm{O}_{3}$ & $\mathrm{CaO}$ & $\mathrm{K}_{2} \mathrm{O}$ & $\mathrm{Na}_{2} \mathrm{O}$ & $\mathrm{MgO}$ & $\mathrm{SO}_{3}$ & LOI \\
\hline $\begin{array}{c}\text { Crystalline } \\
\text { catalyst }\end{array}$ & 20.3 & 1.7 & 4.3 & 30.9 & 0.15 & 5 & 19.4 & 1 & - \\
\hline CPIII 4ORS & 28.22 & 8.36 & 1.78 & 50.01 & 0.40 & 0.26 & 6.05 & 1.77 & 2.45 \\
\hline
\end{tabular}


Evaluation of the chloride penetration and service life of self-healing concretes activated by crystalline catalyst

Table 2

Materials consumption by cubic meter of concrete

\begin{tabular}{|c|c|c|c|c|c|c|c|c|}
\hline \multirow{2}{*}{ Mixture } & w/c ratio & Cement & $\begin{array}{c}\text { Fine } \\
\text { aggregate }\end{array}$ & $\begin{array}{c}\text { Coarse } \\
\text { aggregate } \\
\mathbf{( 4 . 8} \text { to } \\
\mathbf{9 . 5} \mathbf{~ m m})\end{array}$ & $\begin{array}{c}\text { Coarse } \\
\text { aggregate } \\
(\mathbf{9 . 5} \text { to } \\
\mathbf{1 9} \mathbf{~ m m})\end{array}$ & Water & $\begin{array}{c}\text { Plasticizer } \\
\text { admixture }\end{array}$ & $\begin{array}{c}\text { Crystalline } \\
\text { catalyst }\end{array}$ \\
\hline \multirow{2}{*}{$\begin{array}{c}\text { CPIII-40 } \\
\text { RS }\end{array}$} & 0.45 & 398 & 748 & 390 & 728 & 179 & 1.19 & 7.96 \\
\cline { 2 - 9 } & 0.55 & 325 & 813 & 390 & 728 & 179 & 0.98 & 6.5 \\
\cline { 2 - 9 } & 0.65 & 275 & 857 & 390 & 728 & 179 & 0.83 & 5.5 \\
\hline
\end{tabular}

Table 3

Compressive strength and slump test results

\begin{tabular}{|c|c|c|c|}
\hline Mixtures & $\begin{array}{c}\text { Compressive strength } \\
\text { at 28 days (MPa) }\end{array}$ & Slump (mm) & $\begin{array}{c}\text { Cement consumption } \\
\left(\mathbf{k g} / \mathbf{m}^{\mathbf{3}}\right)\end{array}$ \\
\hline $\begin{array}{c}\text { CPIII - } 0.45 \text { without } \\
\text { crystalline catalyst }\end{array}$ & 45.2 & 240 & 398 \\
\hline $\begin{array}{c}\text { CPIII - } 0.45 \text { with } \\
\text { crystalline catalyst }\end{array}$ & 45.8 & 200 & 398 \\
\hline $\begin{array}{c}\text { CPIII - } 0.55 \text { without } \\
\text { crystalline catalyst }\end{array}$ & 42.7 & 220 & 325 \\
\hline $\begin{array}{c}\text { CPIII - } 0.55 \text { with } \\
\text { crystalline catalyst }\end{array}$ & 37.6 & 200 & 275 \\
\hline $\begin{array}{c}\text { CPIII - } 0.65 \text { without } \\
\text { crystalline catalyst }\end{array}$ & 29.9 & 50 & 275 \\
\hline $\begin{array}{c}\text { CPIII - } 0.65 \text { with } \\
\text { crystalline catalyst }\end{array}$ & 29.9 & 50 & 325 \\
\hline
\end{tabular}

\subsection{Specimens preparation}

Concrete mixtures were produced using a vertical axis mixer at three different $w / c$ ratios $(0.45 ; 0.55 ; 0.65)$, with and without crystalline catalyst. Table 2 and 3 show, respectively, the consumption of materials and the test results for characterization and control of the concrete specimens.

Table 3 presents the results of workability for the different mixtures, and it can be verified that for each w/c pair, with and without crystalline catalyst, the slump values were equivalent.

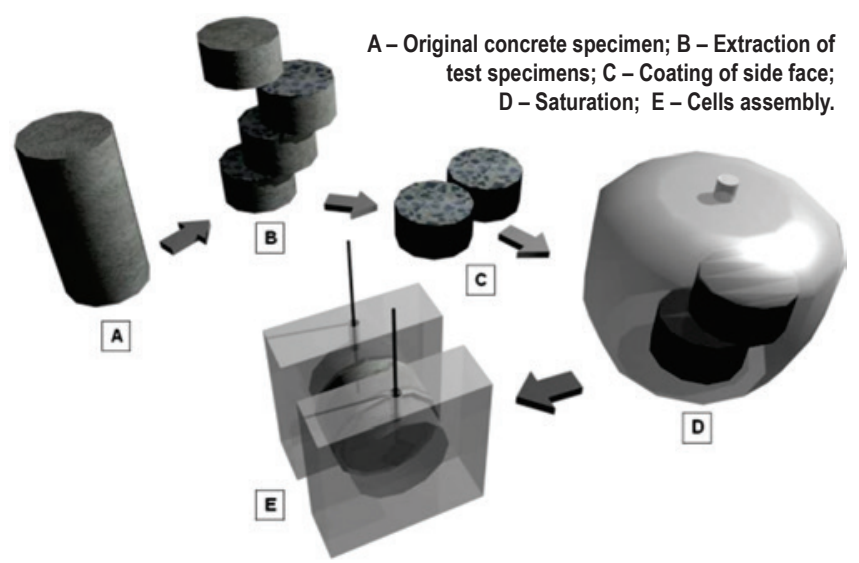

Figure 1

Test procedure

\subsection{Test procedures}

It was performed the rapid chloride permeability test (RCPT) which follows the procedures of Whiting [19] and is recommended by the standard ASTM C1202/12. The cylindrical specimens (51 mm thick and $195 \mathrm{~mm}$ in diameter) were exposed in one side to a sodium chloride solution ( $3 \% \mathrm{NaCl}$ by mass) and the other to a sodium hydroxide solution $(0.3 \mathrm{~N} \mathrm{NaOH})$. A potential difference of $60 \pm$ $0.1 \mathrm{~V}$ is applied, which generate an electric current and induce the chloride anion to diffuse through the concrete under influence of an electric field. Electric current readings were taken using an ammeter every $30 \mathrm{~min}$, totaling $6 \mathrm{~h}$ of test. The electric current multiplied

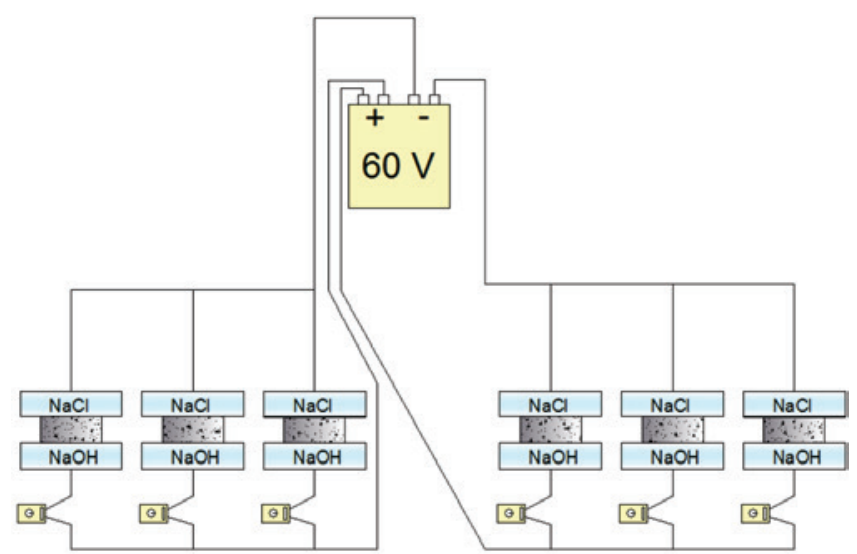

Figure 2

Test graphical representation 


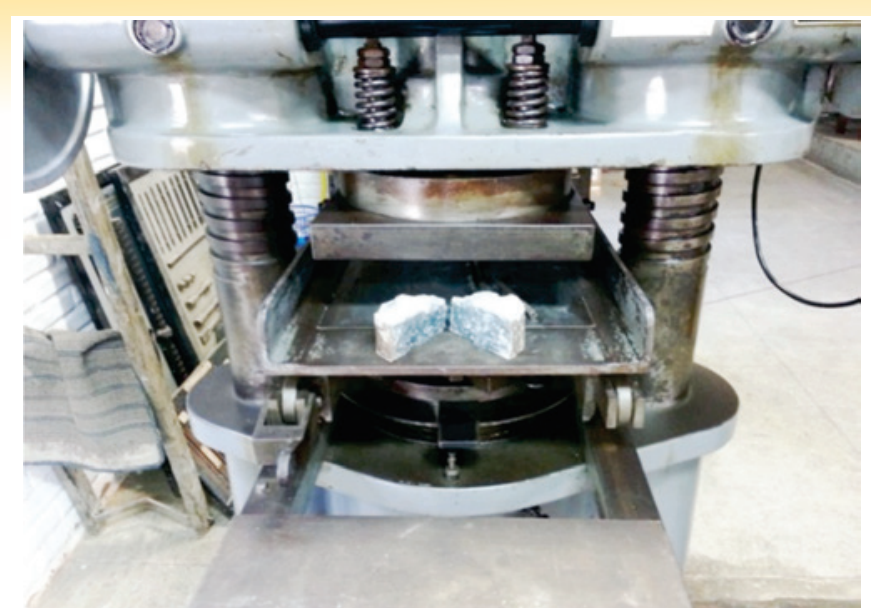

Figure 3

Split specimens

by time, expressed in coulombs (C), indicates the total charge that passed through the specimen and represents the concrete resistance to the chloride ions penetration.

The test procedures were the following. Initially, the specimens were removed from the curing chamber and sawed in 4 parts perpendicular to the vertical axis, being discarded the extremities and used the central parts, procedure statistically validated by Helene e Medeiros [20]. At the following day, the side faces of the specimens were coated with an epoxy resin. A day before testing, the specimens were submitted to vacuum for 4 hours. After 3 hours of removing them from the vacuum, they were submerged in deionized and deaerated water, remaining at this condition for $18 \mathrm{~h}$. At the testing day the samples were removed from the desiccator and coupled to the cells. The test procedure and graphical representation are represented in Figure 1 and 2, respectively.

Completed the RCPT, the specimens were sprayed with silver nitrate aiming to verify the final chloride penetration depth. This procedure was proposed by Luping e Nilsson [21]. For this purpose, the specimens were split in half, using the compressive strength

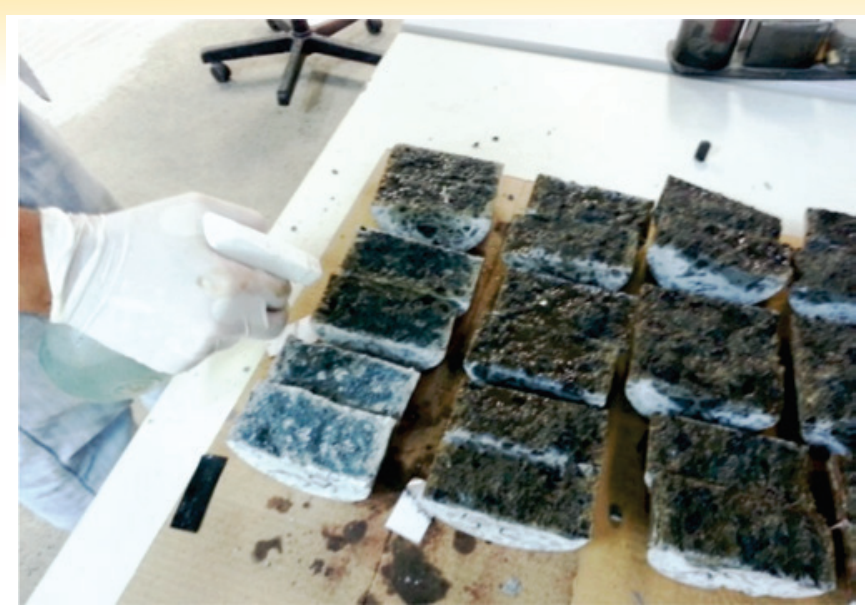

Figure 4

Silver nitrate spray

test apparatus, as shown in Figure 3, and later it was sprayed the silver nitrate, as shown in Figure 4.

\section{Results and discussion}

The tests were performed at the specimens at 28 and 91 days of curing, and the results of total charge passed in Coulombs were identified, according to ASTM C1202, as shown in Figure 5.

It can be identified an increase in total charge passed in higher w/c ratio mixtures, and a decrease due to the use of crystalline catalyst. It can also be noted that at higher $\mathrm{w} / \mathrm{c}$ ratios with the use of catalyst, the results had not changed significantly from 28 to 91 days. It is verified that despite the increase in total charge passed in the mixtures with greater $\mathrm{w} / \mathrm{c}$, the values are still considered 'very low' according to the classification table of total charge passed, as presented in Tables 4 and 5.

The 'very low' classification is justified, mainly, by the cement type used and the curing in a moist chamber for 28 and 91 days. The blast-furnace slag blended cement (CPIII-RS) provides a more compact (dense) and durable concrete. The curing in a moist
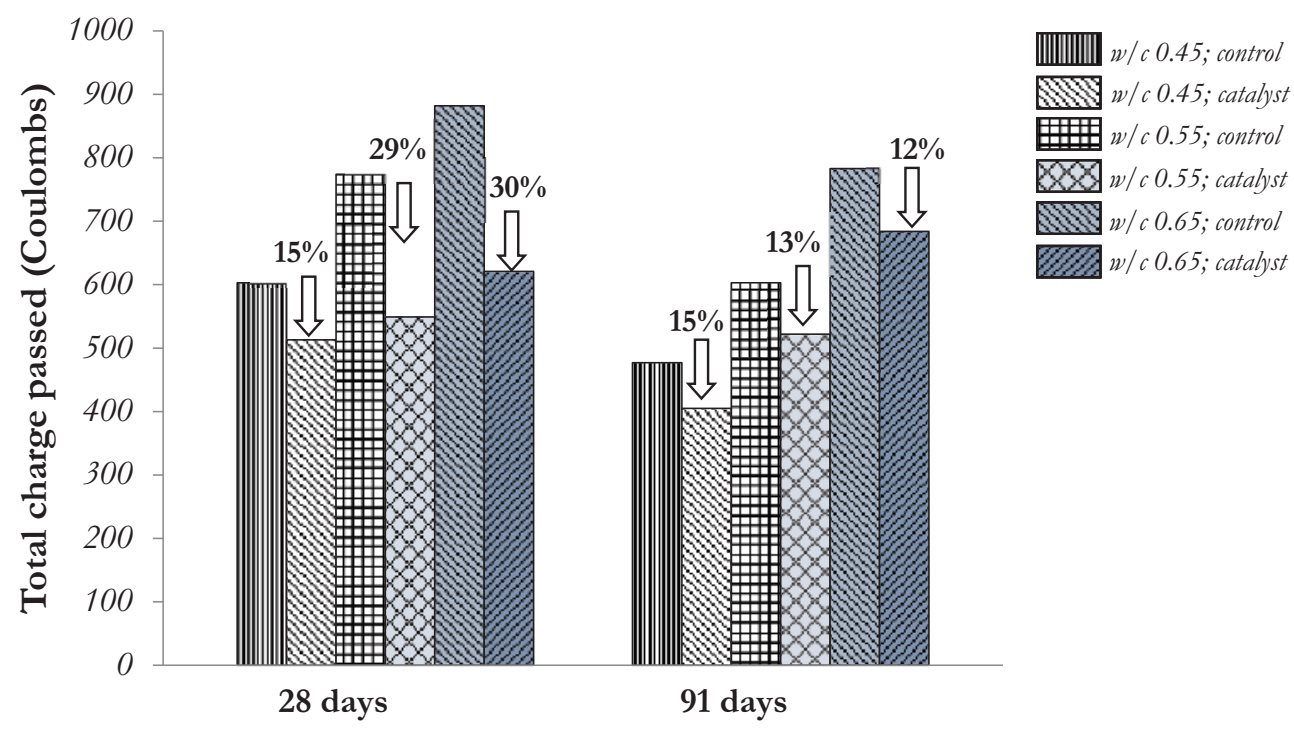

Figure 5

Total charge passed of the different mixtures 
Table 4

ASTM C 1202 Classification

\begin{tabular}{|c|c|}
\hline $\begin{array}{c}\text { Total charge passed } \\
\text { (Coulombs) }\end{array}$ & Chloride ions penetration \\
\hline$>4000$ & High \\
\hline $2000-4000$ & Moderate \\
\hline $1000-2000$ & Low \\
\hline $100-1000$ & Very low \\
\hline$<100$ & Insignificant \\
\hline
\end{tabular}

chamber is a process that provides greater strengths and durability comparatively with the open air curing [22]. It can be observed, in Figure 6, the influence of the w/c ratio with and without crystalline catalyst.

It is noted that for 28 and 91 days an increase of charge passed with the growth of w/c ratio in concrete with and without catalyst (Figure 6). At 91 days, with the varying $w / c$ ratio, it can be noted a constant increase of around $30 \%$.

It is worth mentioning that, despite the similar rise of charge passed with the increase of w/c ratios, at 28 and at 91 days, it is observed smaller changes at 28 days due to catalyst use, comparatively with

\section{Table 5}

Concretes classification

\begin{tabular}{|c|c|c|c|c|}
\hline \multirow{2}{*}{ W/c ratio } & Catalyst & $\begin{array}{c}\text { Age } \\
\text { (days) }\end{array}$ & $\begin{array}{c}\text { Total charge passed } \mathbf{Q} \\
\text { (Coulombs) }\end{array}$ & $\begin{array}{c}\text { Compressive strength } \\
\text { (MPa) }\end{array}$ \\
\hline \multirow{2}{*}{0.45} & With & 28 & 513 & 45.8 \\
\cline { 2 - 5 } & Without & 28 & 603 & 45.2 \\
\hline \multirow{2}{*}{0.45} & With & 91 & 405 & 54.7 \\
\cline { 2 - 5 } & Without & 91 & 477 & 54.1 \\
\hline \multirow{2}{*}{0.55} & With & 28 & 549 & 47.6 \\
\cline { 2 - 5 } & Without & 28 & 774 & 52.7 \\
\hline \multirow{2}{*}{0.55} & With & 91 & 522 & 50.9 \\
\cline { 2 - 5 } & Without & 91 & 603 & 29.9 \\
\hline \multirow{2}{*}{0.65} & With & 28 & 621 & 29.9 \\
\cline { 2 - 5 } & Without & 28 & 882 & 39.5 \\
\hline \multirow{2}{*}{0.65} & With & 91 & 684 & 40.7 \\
\cline { 2 - 5 } & Without & 91 & 783 & \\
\hline
\end{tabular}

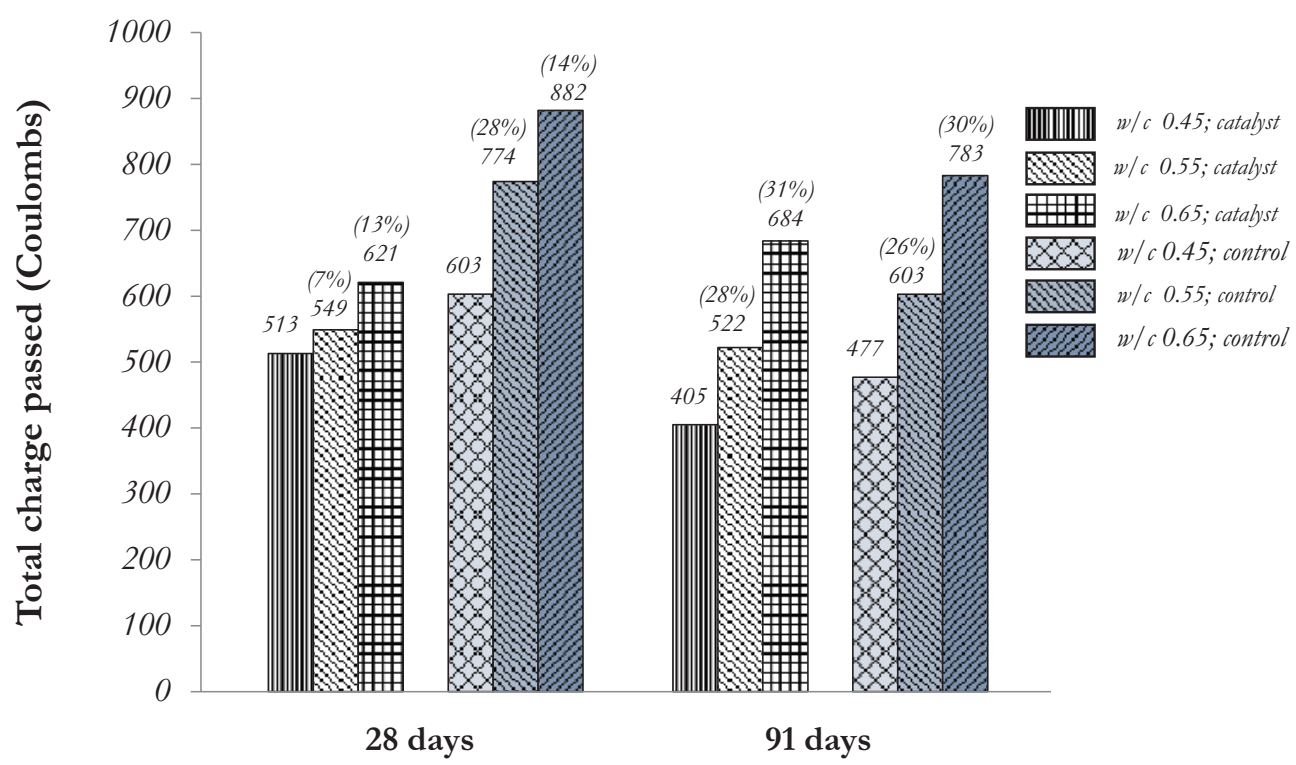

Figure 6

Influence of catalyst use on total charge passed 


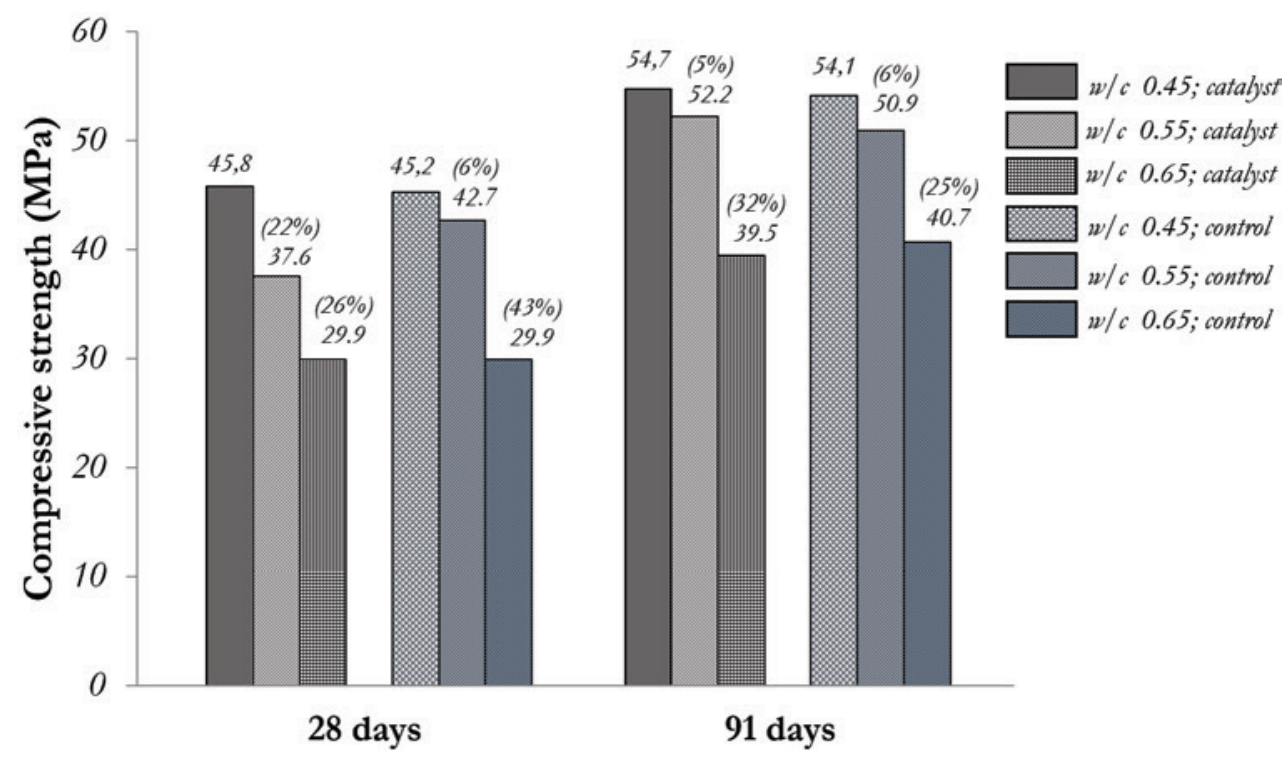

\section{Figure 7}

Influence of catalyst use on compressive strength

the same w/c ratio increase at 91 days. The mentioned above can be due, probably, to the products of the concrete pores crystallization mechanism reacting with the concrete microstructure at early ages.

\subsection{Compressive strength}

In figure 7, it can be observed the compressive strength test results obtained from the variation of age, w/c ratios and use of crystalline catalyst.

By processing the results according to the least squares method it can be obtained the characteristic curves of the Abrams' law
[23], as shown in Figure 8. From this figure, it can be noted that the use of crystalline catalyst do not hinder the concrete compressive strength.

\subsection{Chlorides penetration - colorimetric test}

Completed the RCPT (ASTM C1202) at the 28 and 91 days specimens, they were split and sprayed with silver nitrate, and the results can be seen in Figure 9.

From the exposed results (Figure 9) it can be identified a rise in the chloride penetration depth with the increase of w/c ratio from

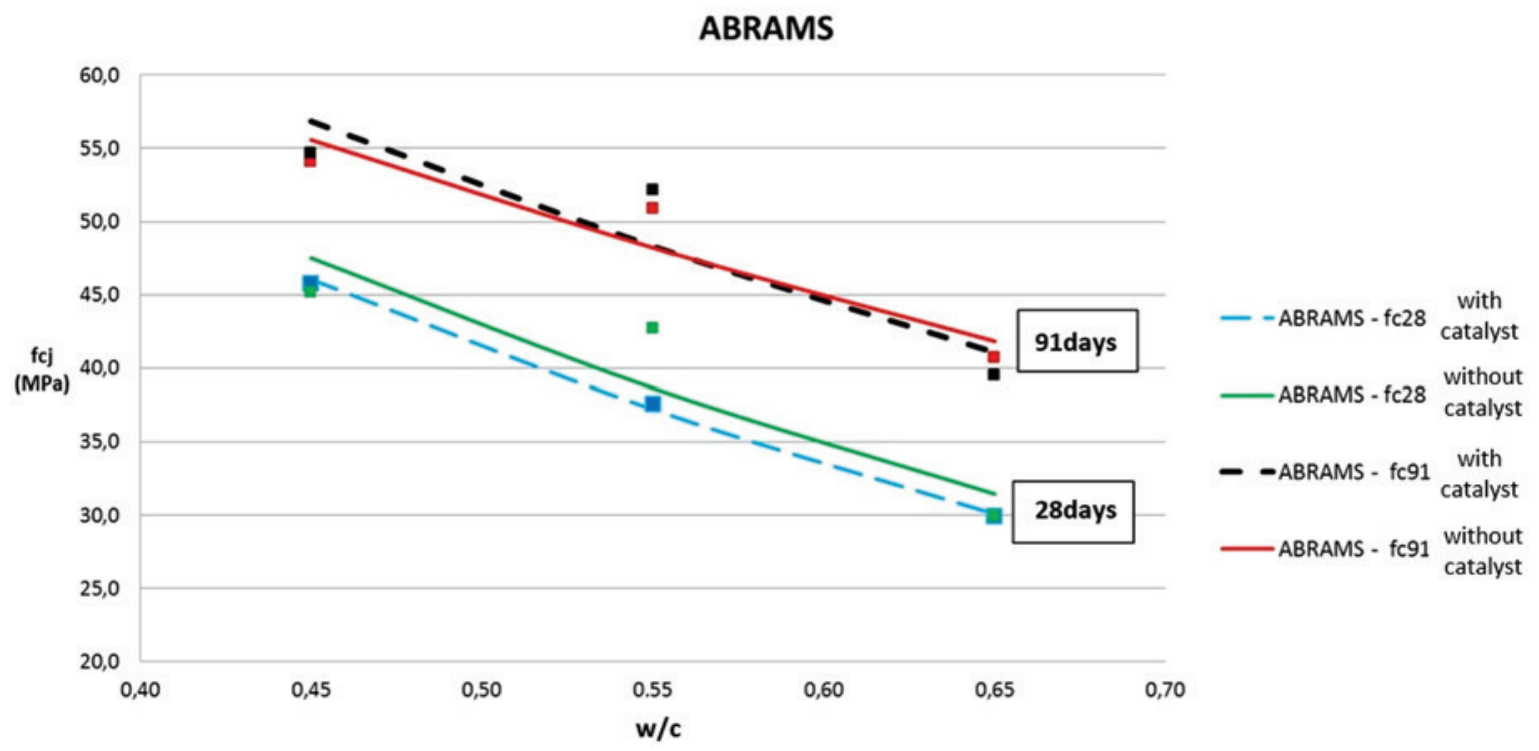

Figure 8

Characteristic curves of Abram's law 


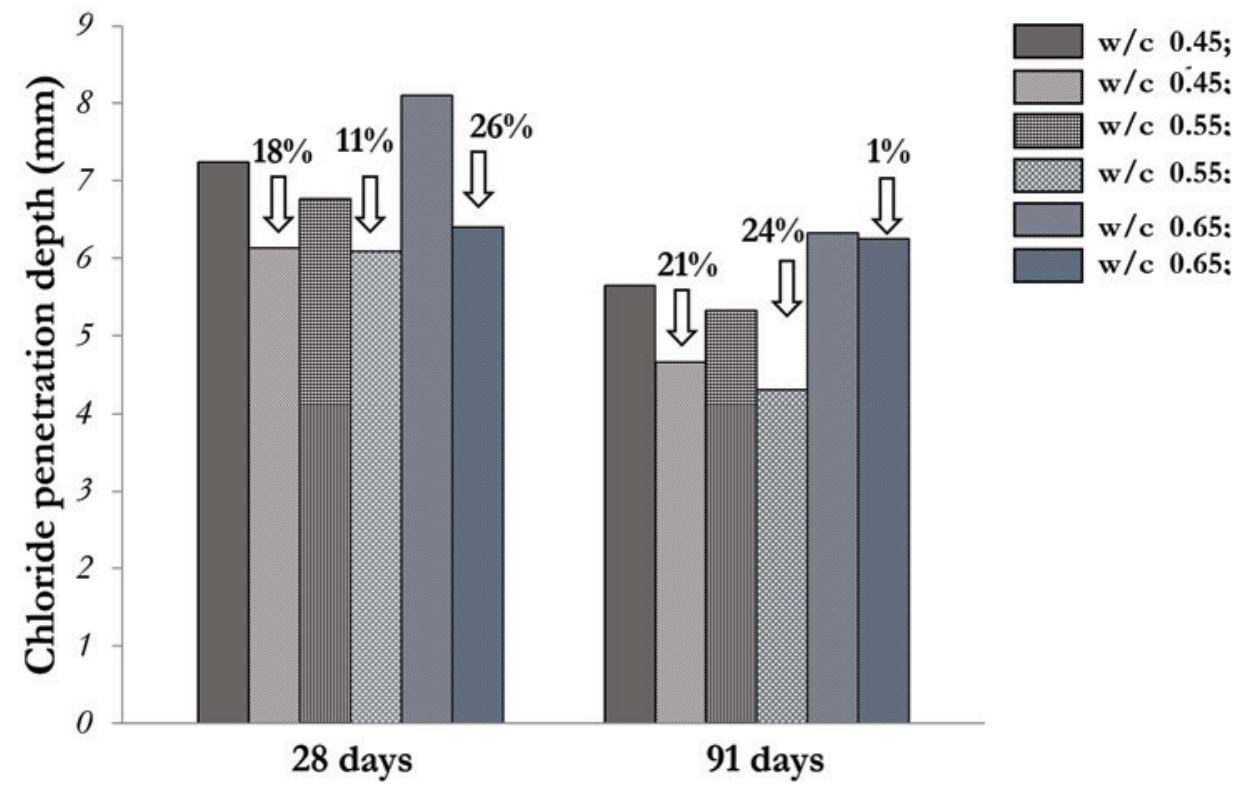

\section{Figure 9}

Chloride penetration depth at the different mixtures

0.45 to 0.65 . It can also be noted a reduction in the penetration depth with the use of the crystalline catalyst, with average values, generally, $20 \%$ lower.

\subsection{Chloride diffusion coefficient}

Aiming at analyze the results of chloride apparent diffusion coefficient it can be adopted the recommendation of Berke and Hicks [24], where the correlation between the total passed charge and chlorides diffusion coefficient are considered. The model proposed by Berke and Hicks [24] can be adopted to estimate the project service life of reinforced concrete structures (time to initiate the reinforcement depassivation by chlorides), and also the formation of cracks in concretes subjected to an environment with salt spray. Due to the exposed, it was proposed the Equation 1 to derive empirically the chloride diffusion coefficient estimate using the results of total charge passed related to the RCPT (ASTM C1202). This equation was adopted by other authors such as Helene and Medeiros [25] and Andrade and Whiting [26].

$C_{d a}=0,0103 \times 10^{-8} Q^{0,84}$

Where: $C_{d a}=$ Chloride apparent diffusion coefficient $\left(\mathrm{cm}^{2} / \mathrm{s}\right) ; \mathrm{Q}=$ total charge passed (Coulomb).

From the chloride diffusion coefficient determined by the method proposed by Berke and Hicks [24] and adopting the Fick's second law of diffusion in the non-steady-state, it is possible to build to draw a graph relating the chloride penetration depth with the service life of the structure.

For the service life prediction, it was used Equations 2 and 3 developed from the Fick's second law [27-29].

$P_{C l}=2(z) \sqrt{D t}$
$\operatorname{erf}(z)=1-\frac{C_{C l}-C_{0}}{C_{s}-C_{0}}$

Where: $\mathrm{D}$ is the chloride diffusion coefficient ( $\mathrm{cm}^{2} /$ year); $\mathrm{t}$ is the service life (years); erf $(z)$ is the Gauss error function; $P_{C l}$ is the chloride penetration depth in which the chloride concentration reached a critical point for depassivation of reinforcement $(\mathrm{cm}) ; \mathrm{C}_{0}$ is the initial chlorides concentration inside the specimens (adopted $0 \%$ ); $\mathrm{C}_{\mathrm{S}}$ is the chlorides concentration in the specimens surface (\%); $\mathrm{C}_{\mathrm{Cl}}$ is the chlorides concentration limit for depassivation of reinforcement by chloride attack over the $\mathrm{P}_{\mathrm{Cl}}$ depth and time $\mathrm{t}(\%)$.

For creating the graph, some parameters were fixed. The upper limit value for depassivation of reinforcement was considered as $0.4 \%$, related to the cement mass. This value was adopted since it is the upper limit of chlorides for reinforced concrete according to The International Federation for Structural Concrete (CEB-FIP). It is also an average value between the Brazilian ABNT NBR 6118:2014 standard of $0.5 \%$ and the American $\mathrm{ACl}-318$ standard of $0.3 \%$.

The chlorides concentration in the concrete surface adopted was $0.9 \%$, value recommended by Helene [1] as a reference for concretes with w/c ratio ranging from 0.48 to 0.68 , cement consumption of 280 to $400 \mathrm{~kg} / \mathrm{m}^{3}$ and subjected to salt spray.

However, the chlorides concentration value at the concrete surface, considering salt spray environments, is object of controversy. Medeiros [28] recommends an average value of $1.8 \%$, which, according to the author, is an average value from the value of $0.9 \%$ recommended by Helene [1] and the $3.0 \%$, for a real structure 22 years old and subjected to salt spray, recommended by Guimarães [30]. Nunes et al. [31] evaluated concrete structures in the use phase, older than 15 years and at different distances from the sea and found the following values: $\mathrm{Cs}=$ $3.1 \%$ at $0 \mathrm{~m}$ sea distance; $\mathrm{Cs}=1.1 \%$, at $160 \mathrm{~m}$; and $\mathrm{Cs}=0.6 \%$, at 630 $\mathrm{m}$. Guimarães et al. [32] suggest the following value of Cs for service life prediction: $3.2 \%$ at $0 \mathrm{~m}$ sea distance; $1.1 \%$ at $160 \mathrm{~m}$; and $0.6 \%$ at a 


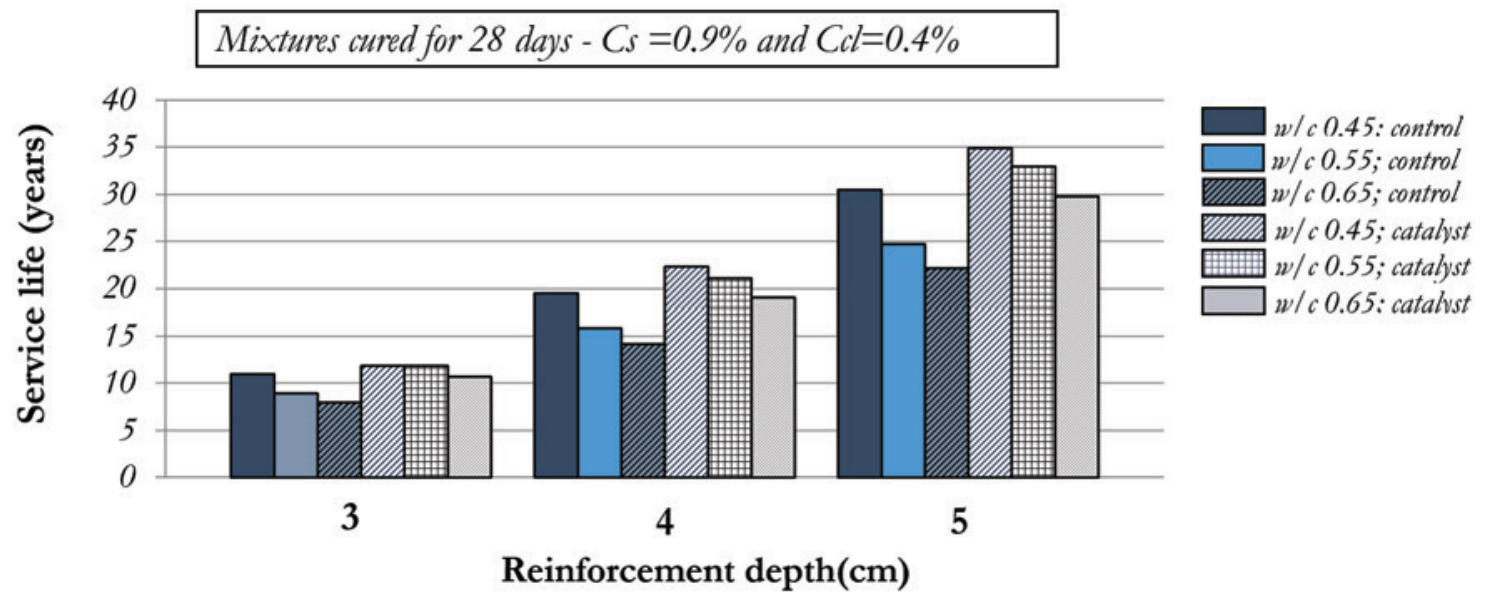

Figure 10

Service life prediction - based in the mixtures cured for 28 days

distance between 680 and $5.000 \mathrm{~m}$ from the sea. Thus, the $0.9 \%$ value adopted in this study is consistent with the presented literature.

It is important to emphasize that, according to Andrade [33], the service life presented in this study is only valid in the following conditions: the reinforced concrete is at the beginning of its service life (initiation period); the fastest aggressive agent to the structure is the chloride attack, disregarding the others; the concrete subjected to salt spray or submerged in a saline solution without additional external accidental factor would affect the properties of the concrete cover. From the equation 2, the graph presented in Figure 10 relates the reinforcement depth adopted with the service life prediction (initiation period of corrosion by chloride) for the analyzed mixtures. The reinforcement depths of 3,4 and $5 \mathrm{~cm}$ were adopted since they are the values recommended by Brazilian standard ABNT NBR 6118:2014 for the following environmental conditions, respectively: urban area and moderate aggressiveness; maritime area and strong

\section{Table 6}

Service life increase due to catalyst use

\begin{tabular}{|c|c|c|c|}
\hline $\begin{array}{l}\text { Reinforcement depth } \\
\text { (cm) }\end{array}$ & Mixture & Service life (years) & Service life increase (\%) \\
\hline \multirow{6}{*}{3} & w/c 0.45; control & 11.0 & \multirow{2}{*}{$15 \%$} \\
\hline & w/c 0.45; catalyst & 12.5 & \\
\hline & w/c 0.55; control & 8.9 & \multirow{2}{*}{$33 \%$} \\
\hline & w/c 0.55; catalyst & 11.9 & \\
\hline & w/c 0.65; control & 8.0 & \multirow{2}{*}{$34 \%$} \\
\hline & w/c 0.65; catalyst & 10.7 & \\
\hline \multirow{6}{*}{4} & w/c 0.45; control & 19.5 & \multirow{2}{*}{$15 \%$} \\
\hline & w/c 0.45; catalyst & 22.3 & \\
\hline & w/c 0.55; control & 15.8 & \multirow{2}{*}{$33 \%$} \\
\hline & w/c 0.55; catalyst & 21.1 & \\
\hline & w/c 0.65; control & 14.2 & \multirow{2}{*}{$34 \%$} \\
\hline & w/c 0.65; catalyst & 19.0 & \\
\hline \multirow{6}{*}{5} & w/c 0.45; control & 30.5 & \multirow{2}{*}{$15 \%$} \\
\hline & w/c 0.45; catalyst & 34.9 & \\
\hline & w/c 0.55; control & 24.7 & \multirow{2}{*}{$33 \%$} \\
\hline & w/c 0.55; catalyst & 33.0 & \\
\hline & w/c 0.65; control & 22.1 & \multirow{2}{*}{$34 \%$} \\
\hline & w/c 0.65; catalyst & 29.7 & \\
\hline
\end{tabular}


aggressiveness; and splash zone and very strong aggressiveness. It was considered for the analysis, the mixtures cured for 28 days since at this age the hydration reactions are in a mature stage, and also due to the more significant results of the crystalline catalyst effect than at 91 days.

Based in the Figure 10 and Table 6 , it can be noted that by adopting a reinforcement depth of $4 \mathrm{~cm}$, as recommended in the ABNT NBR 6118 (2014) standard for reinforced concrete structures exposed to marine environment, and $w / c$ ratio of 0.65 , it is obtained a service life of approximately 14 years for the control mixture and 19 years by using catalyst ( $34 \%$ increase). At $0.65 \mathrm{w} / \mathrm{c}$ ratio with 5 $\mathrm{cm}$ of reinforcement depth, it is estimated a service life of 22 years for the control mixtures and nearly 30 years by using the catalyst, representing a $34 \%$ increase. By adopting a $5 \mathrm{~cm}$ concrete cover, the highest value indicated by the standard, and $0.45 \mathrm{w} / \mathrm{c}$ ratio, it is predicted a service life of 30 years for the control mixture and 35 years by using the crystalline catalyst.

\section{Conclusions}

After the tests completion, the following can be concluded in this study:

- The crystalline catalyst did not altered the concrete properties at fresh state and improved its hardened properties, providing a reduction in chloride penetration without compromising the mechanical compressive strength;

- The improvements were more significant at 28 days, nevertheless, they were prolonged till 91 days;

- The average reduction in total charge passed, in Coulombs, in the ASTM C1202 test was 15\%;

- Regarding the chloride penetration test by silver nitrate spray, a reduction in the chloride contaminated depth at 91 days was noted, meaning a higher resistance to chloride ions penetration at this later age. It was also observed that, as the results from the ASTM C1202 test, there was an increase in resistance against chloride penetration with the lower $w / c$ ratios and the use of crystalline catalyst;

- In relation to the service life prediction, the use of crystalline catalyst provided an increase of up to $34 \%$ in the analysed mixtures.

\section{References}

[1] HELENE, Paulo. Contribuição ao estudo da corrosão em armaduras de concreto armado. 1993. 248p. (Habilitation thesis) Escola Politécnica, Universidade de São Paulo.

[2] TANG, L. Chloride Transport in Concrete - Measurement and prediction, Doctoral thesis, Dept. of Building Materials, Chalmers Universities of Technology, Publication P-96:6, Gothernburg, Sweden, 1996.

[3] ANDRADE, C. Manual para diagnóstico de obras deterioradas por corrosão de armaduras, Ed. Pini, SãoPaulo, 1986.

[4] Basher, L.; Kroop, J. Cleland, Assessment of the durability of concrete form its permeation properties: a review, Construction and Building Material. 15 (2001) 93-103.

[5] SOUSA, V. C. M. - Patologia, Recuperação e Reforço de Estruturas de Concreto. São Paulo: PINI, 1998, 255 p.

[6] NEVILLE, A. M., Tecnologia do concreto, $2^{\mathrm{a}}$ ed., Pini, São Paulo, 2010.
[7] Tittleboom, K. V.; Snoeck, D.; Wang, J.; De Belie, N. Most recent advances in the field of self-healing cementitious materials. In: 4th International Conference on Self-Healing Materials. Ghent, Belgium: Proceedings... p. 406-413, 2013.

[8] RILEM. Self-healing phenomena in cement-based materials. Heidelberg: Springer Netherlands, v. 11. 2013.

[9] Sisomphon, K.; Copuroglu, O.; Koenders, E. A. B. Selfhealing of surface cracks in mortars with expansive additive and crystalline additive. Cement Concrete Composite, 2012;34:566-74.

[10] Kuramoto, Y.; Matsuda, Y.; Nakamura, Y.; Irie, M. Verification of suppression of AAR by a metal carrying complex compound. In: Proceedings of 11th international conference of alkali-aggregate reaction in concrete. Quebec, Canada; 2000:1-9[in CD]

[11] Xiao, X.; Zhang, Q.S.; Liang X.Y.; Zhang, X.N. Research on Chloride Ion Diffusion of Concrete Water-Based Capillary Crystalline Waterproofer and its Penetration Depth by Using Electron Microscope Advanced, Materials Research, 857 (2013) 27-34

[12] Ourives, C. N.; Bilesky, P. C. Avaliação do Desempenho dos Sistemas de Impermeabilização por Cristalização Capilar do Concreto. In: $50^{\circ}$ Congresso Brasileiro do Concreto - Ibracon, Salvador, Brasil, 2008.

[13] Helene, Paulo; M. Lima; Maryangela. G.; Takagi, E.. M. Selfhealing of self-compacting concretes made with brazilian blast furnace slag cements activated by crystalline catalyst. XII DBMC 02-05 de Setembro 2014 São Paulo- Brazil

[14] Helene, Paulo; Takagi, E. M.; Lima, M.G. Contribution to study of the self-healing effect activated by crystalline catalysts in concrete structures when subjected to continuous exposure to water. In: International Conference on Concrete Repair, Rehabilitation and Retrofitting, 2012, Cape Town. Proceeding of 3rd International Conference of Concrete Repair, Rehabilitation and Retrofitting. Cape Town: CRC Press, 2012. V. III. P. 1415-1419.

[15] Almeida, I. R. A onda de concreto que flutua no M.A.R. Revista Concreto \& Construções, IBRACON, V. 72, P. 100-110, Out-Dez. 2013

[16] Helene, Paulo; Britez, C.; Bueno, S.; Pacheco, J. "Estanqueidade de lajes de subpressão. Caso MIS-RJ" In: Anais do $55^{\circ}$ Congresso Brasileiro do Concreto, 2013, Gramado-RS.

[17] Teng L.; Huang, R.; Chen, J.; Cheng, A; Hsu, H. A study of crystalline mechanism of penetration sealer materials. Materials (2014), 399-412.

[18] Yodmatai, D. et al. Eater sorptivity, water permeability, autogenous shrinkage and compressive strength of concrete with crystalline materials. In: 15th nationala convention on civil engineering. 2010. Ubonrachatani: Proceedings

[19] Whiting, D. Rapid determination of the chloride permeability of concrete. Final Report No. FHWA/RD-81/119, Federal Highway Administration, August 1981, NTIS No. 82140724.

[20] Medeiros, M. H. F.; Borba, A. Y.; Filho, J. H.; Paulo Helene. Ensaio de migração de cloretos para concreto: influência do número de fatias extraídas", Revista Escola de Minas, Ouro Preto-MG (2012) 475-481. 
[21] Luping, T. Nilsson, L. "Rapid determination of the chloride diffusivity in concrete by applying an electrical field." ACI Materials Journal, v. 89, n.1, (1992) 49-53.

[22] MEHTA, P. K.; Monteiro, P. J. M. Concreto: Microestrutura, Propriedades e Materiais, $2^{\text {a }}$ Ed., IBRACON, São Paulo, 2014.

[23] Monteiro, Paulo; Helene, Paulo \& KANG, S. Designing Concrete Mixtures for Strength, Elastic Modulus and Fracture Energy. Materials \& Structures, v.26, p.443 - 452, 1993

[24] Berke, N.S., Hicks, M.C. Estimating the life cycle of reinforced concrete decks and marine piles using laboratory diffusion and corrosion data. Corrosion forms and control of infrastructure, ASTM STP 1137, V. Chacker ad. ASTM. Philadelphia, 1992. p. 207-231.

[25] Medeiros, M. H. F.; Gobbi, A.; Groenwold, J. A.; Paulo Helene. Previsão da vida útil de concreto armado de alta resistência com adição de metacaulim e sílica ativa em ambientes marinhos, Revista Escola de Minas, Ouro Preto-MG (2013) 59-65.

[26] Andrade, C.; Whiting, D. A comparison of chloride ion diffusion coefficients derived from concentration gradients and non-steady state accelerated ionic migration. Materials and Structures, v. 29, p. 476-484, 1996.

[27] Helene, Paulo (2000), "Durabilidad. Interpretación y evaluación de resultados. Manual de Diagnosis e Intervención en Estructuras de Hormigón Armado" (Barcelona, Espanha: Collegi d'Aparelladors i Arquitectes Tècnics de Barcelona), 1th edn., p. 87-102.

[28] Medeiros, M. H. F. (2008), "Contribuição ao estudo da durabilidade de concretos com proteção superficial frente à ação de íon cloretos." Tese de Livre Docência, Escola Politécnica, Universidade de São Paulo, São Paulo.

[29] Ribeiro, D. V. (2014), Corrosão em Estruturas de Concreto Armado: Teoria, Controle e Métodos de Análise. São Paulo: Elsevier.

[30] GUIMARÃES, A. T. da C. Vida útil de estruturas de concreto armado em ambientes marítimos. 2000. 241 p. Tese (Doutorado) - Escola Politécnica, Universidade de São Paulo, 2000.

[31] NUNES, J. L. 0.; Guimarães, A. T. C.; Silveira, B. P.; Guimarães, D. L. C.; Oliveira, M. T.; Rodrigues, N. D. Intensidade de ataque de cloretos: considerações sobre a distância do concreto em relação à água do mar. In: Seminário e Workshop em Engenharia Oceânica - SEMENGO. Rio Grande, FURG, 2004.

[32] GUIMARÃES, A.T.C., CASTRO, P., NUNES, J.L.O., "Teor de Cloretos Próximos a Superfície do Concreto em Ambientes Marítimos", In: Anais do $49^{\circ}$ Congresso Brasileiro do Concreto, Bento Gonçalves, Rio Grande do Sul, Brasil, 2007.

[33] ANDRADE, J. J. (2005), "Vida útil das estruturas de concreto." In: Concreto: Ensino. Pesquisas e Realizações. Geraldo Isaia (Ed.). Ibracon, São Paulo, p.923-951. 